\title{
Isolation and characterization of hydrocarbon-degrading bacteria from gas station leaking-contaminated groundwater in the Southern Amazon, Brazil
}

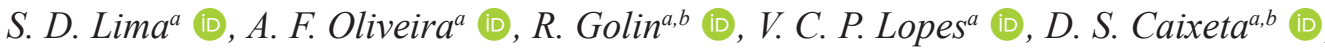 \\ Z. M. Lima ${ }^{a, b}$ (D) and E. B. Morais $a, b *$ (iD \\ aPrograma de Pós-graduação em Recursos Hídricos, Faculdade de Arquitetura, Engenharia e Tecnologia, \\ Universidade Federal de Mato Grosso - UFMT, Av. Fernando Corrêa da Costa, 2367, Boa Esperança, \\ CEP 78060-900, Cuiabá, MT, Brasil

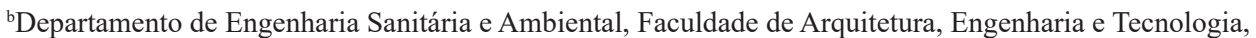 \\ Universidade Federal de Mato Grosso - UFMT, Av. Fernando Corrêa da Costa, 2367, Boa Esperança, \\ CEP 78060-900, Cuiabá, MT, Brasil \\ *e-mail: beraldo_morais@yahoo.com.br
}

Received: July 24, 2018 - Accepted: October 26, 2018 - Distributed: May 31, 2020

(With 4 figures)

\begin{abstract}
Twenty-three hydrocarbon-degrading bacteria strains were isolated from gas station leaking-contaminated groundwater located in the Southern Amazon, Brazil. Based on hydrocarbon (diesel, hexadecane, benzene, toluene and xylene) degradation ability, two strains were selected for further study. The amplification and sequencing of the 16S rRNA gene showed that these two strains belonged to the genus Bacillus (Bacillus sp. L26 and Bacillus sp. L30). GC-MS analysis showed that strain L30 was the most effective in degrading n-alkane $\left(\mathrm{C}_{10}-\mathrm{C}_{27}\right)$ from diesel after 7 days of cultivation in mineral medium. Both strains produced biosurfactants and showed emulsification activity, specially the strain L30. Alkane hydroxylase gene (group III), which is important for alkane biodegradation, was present in strains. As a result, this study indicated that these bacteria could have promising applications in hydrocarbon bioremediation.
\end{abstract}

Keywords: alkanes, diesel, biodegradation, alkB gene, biosurfactant.

\section{Isolamento e caracterização de bactérias degradadoras de hidrocarbonetos de água subterrânea contaminada por vazamentos em posto de combustível no sul da Amazônia, Brasil}

\begin{abstract}
Resumo
Vinte e três linhagens bacterianas degradadoras de hidrocarbonetos foram isoladas de água subterrânea contaminada por vazamento em posto de combustível no sul da Amazônia, Brasil. Com base na habilidade de degradar hidrocarbonetos (diesel, hexadecano, benzeno, tolueno e xileno), duas linhagens foram selecionadas para estudos posteriores. A amplificação e sequenciamento do gene 16S rRNA demonstrou que essas linhagens pertencem ao gênero Bacillus (Bacillus sp. L26 and Bacillus sp. L30). Análises de GC-MS mostraram que a linhagem L30 foi mais eficiente em degradar n-alcanos $\left(\mathrm{C}_{10}-\mathrm{C}_{27}\right)$ presentes no diesel, após 7 dias de cultivo em meio mineral. Ambas as linhagens produziram biossurfactantes e apresentaram atividade emulsificante, especialmente a linhagem L30. O gene alcano hidroxilase (grupo III), o qual é importante para degradação de alcanos, foram detectados nas linhagens. Como resultado, este estudo indicou que essas linhagens bacterianas podem ser promissoras se aplicadas em processos de biorremediação.
\end{abstract}

Palavras-chave: alcanos, diesel, biodegradação, gene alk-B, biossurfactantes.

\section{Introduction}

Petroleum-based products include a wide variety of hazardous compounds like n-alkane, cycloalkane and aromatic hydrocarbon. During petroleum large scale exploration, transport, processing, storage and use, contaminated sites may arise as consequence of accidents and operational activities (Hassanshahian et al., 2012). In gas station fuel spills may occur mainly during leakage of underground storage tanks, which can result in soil and groundwater contamination. Once contaminated, water and soil should be remediated to ensure human health and balance of ecosystems.

A variety of remediation techniques are currently available to treat hydrocarbon-contaminated soil and 
groundwater. Technologies like soil washing, soil vapor extraction, stabilization and solidification, encapsulation, solvent extraction, air sparging, pump-and-treat technology, passive/reactive treatment walls and incineration have been used to remediate contaminated sites (Varjani, 2017). Many of these technologies, however, are either costly or do not result in complete destruction of contamination. On the other hand, bioremediation is a technology based on natural biological processes, in which microorganisms can degrade and even mineralize hazardous compounds with low environmental impact, costs and energy requirements (Morais and Tauk-Tornisielo, 2009). Bioremediation has been demonstrated as an appropriate and effective alternative to clean-up hydrocarbon-contaminated environments (Varjani and Upasani, 2016; Varjani, 2017).

Biostimulation and bioaugmentation are main approaches of bioremediation. Biostimulation involves nutritional amendment ( $\mathrm{N}$ and $\mathrm{P}$ ), oxygenation, temperature and $\mathrm{pH}$ control, and addition of surfactant in contaminated sites to stimulate the growth of indigenous hydrocarbon degraders and to increase biodegradation rates. Bioaugmentation includes adding hydrocarbon-degrading microorganisms to the contaminated environment to supplement the existing biodegrading microbial communities (Abed et al., 2014; Hassanshahian et al., 2014). Thus, the isolation and selection of hydrocarbon-degrading microorganisms are important steps in a bioremediation program. From microbial isolates, it is possible to study in more detail the enzymes, metabolic pathways, and environmental factors involved in hydrocarbon biodegradation.

Many hydrocarbon-degrading bacteria have been isolated from soil (Varjani and Upasani, 2016), sediments (Abed et al., 2014) and seawater (Uad et al., 2010;
Hassanshahian et al., 2012). However, the number of the bacterial genera with the ability to degrade petroleum hydrocarbons isolated from groundwater is lower than the genera isolated from those environments. The aims of the present study were to isolate and to characterize metabolic capabilities of hydrocarbon-degrading bacteria from contaminated groundwater in a gas station located in the municipality of Alta Floresta (State of Mato Grosso) in the Southern Amazon, Brazil. The steps included enrichment and isolation of hydrocarbon-degrading bacteria, morphological and biochemical characterization, 16S rRNA gene sequence analysis, and screening test in order to detect the presence of alkane hydroxylase gene (alkB). In addition, it was evaluated the ability of bacteria to biodegrade diesel and to produce biosurfactant.

\section{Material and Methods}

\subsection{Samples and reagents}

For isolation of hydrocarbon-degrading bacteria, groundwater were collected from two contaminated monitoring wells in a gas station (Latitude: $9^{\circ} 53$ 'S; Longitude: $56^{\circ} 5^{\prime} \mathrm{W}$ ) in the municipality of Alta Floresta, State of Mato Grosso, Brazil. This municipality is located in the Southern Amazon of Brazil (Figure 1). According to state environmental agency, this area is contaminated since 2006 and several remediation strategies have been applied without success. Groundwater samples $(100 \mathrm{~mL}$, triplicate) were collected in September 2014 using sterile groundwater monitoring tubes of polyethylene (bailer), $\varnothing 41 \mathrm{~mm}$, and transported on ice to the laboratory for isolation.

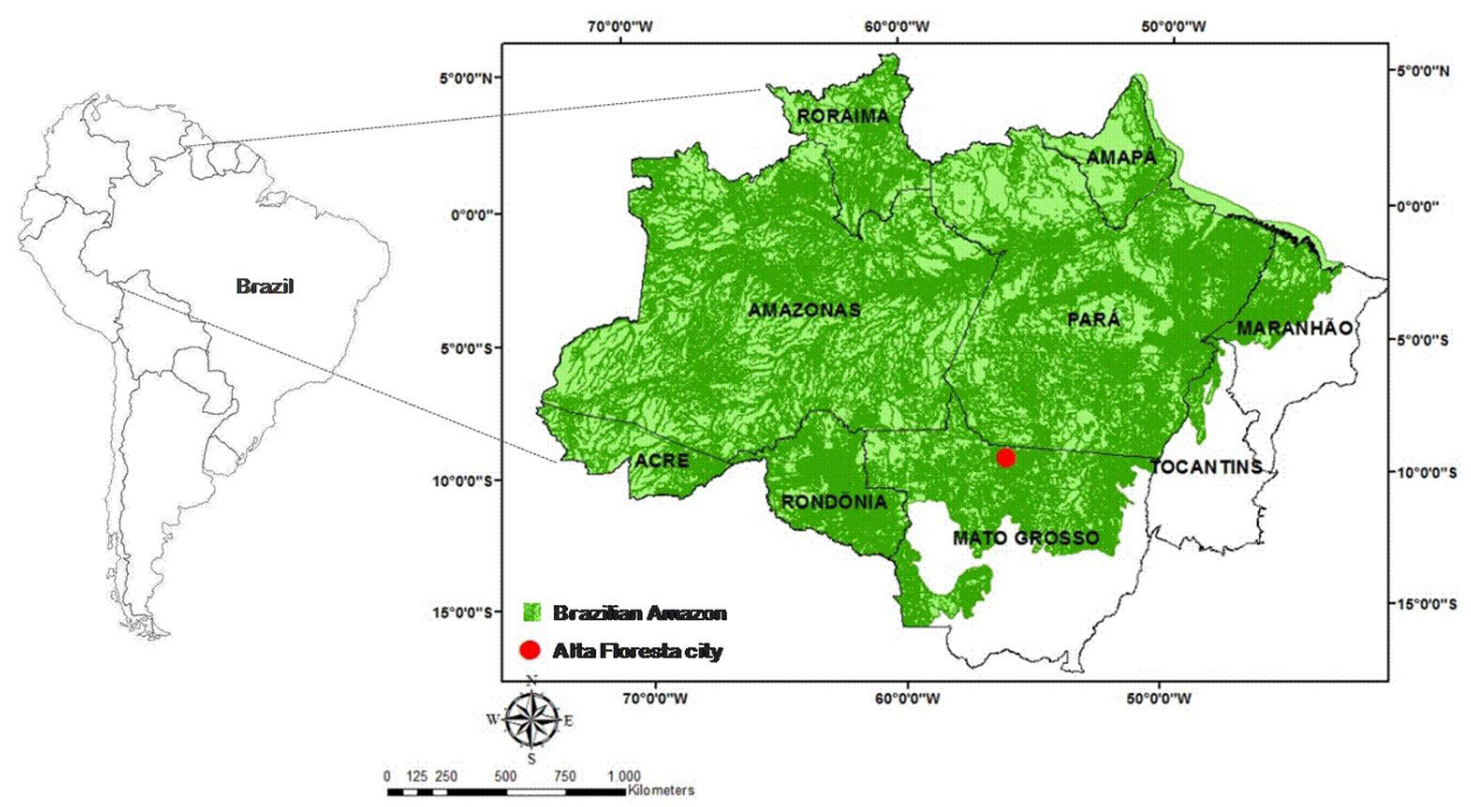

Figure 1. Location of the municipality of Alta Floresta in Southern Amazon of Brazil, where hydrocarbon-contaminated groundwater was collected and used to isolate hydrocarbon-degrading bacteria. 
Benzene, toluene, xylene, hexadecane, cyclohexane and other chemical reagents used were of analytical grade. Diesel oil was purchased from the same gas station in Alta Floresta and was sterilized by filtration (filter membranes $\varnothing 0.22 \mu \mathrm{m})$. Distilled water was used for preparation of all culture media.

\subsection{Enrichment and isolation of hydrocarbon- degrading bacteria}

Bushnell-Haas medium (BH) (Bushnell and Haas, 1941) was used for the enrichment of hydrocarbon-degrading bacteria. The $\mathrm{BH}$ medium consists, per liter, of: $0.2 \mathrm{~g} \mathrm{MgSO}_{4}$, $0.02 \mathrm{~g} \mathrm{CaCl}_{2}, 1.0 \mathrm{~g} \mathrm{~K}_{2} \mathrm{HPO}_{4}, 1.0 \mathrm{~g} \mathrm{KH}_{2} \mathrm{PO}_{4}, 1.0 \mathrm{~g} \mathrm{NH}_{4} \mathrm{NO}_{3}$, $0.05 \mathrm{~g} \mathrm{FeCl}_{3}, \mathrm{pH} 7.0$. BH was supplemented with $1 \%(\mathrm{v} / \mathrm{v})$ diesel as the sole carbon source. Aliquots of groundwater $(3 \mathrm{~mL}$ ) were added to $250 \mathrm{~mL}$ Erlenmeyer flasks containing $100 \mathrm{~mL}$ sterile BH medium supplemented with diesel and the flasks were incubated at $30^{\circ} \mathrm{C}$ for 7 days on rotary shaker $(150 \mathrm{rpm})$. Then, $3 \mathrm{~mL}$ aliquots were taken and inoculated in fresh $\mathrm{BH}$ medium and incubated in same conditions. After a series of six further subculture, $1 \mathrm{~mL}$ aliquot was taken from the medium, diluted in sterile saline solution $(0.85 \% \mathrm{w} / \mathrm{v})$ and plated on Nutrient Agar (NA) medium (Himedia Labs) for incubation at $30{ }^{\circ} \mathrm{C}$. After $48 \mathrm{~h}$, phenotypically different colonies were picked out for purification on NA medium. The NA medium consists, per liter, of: $5.0 \mathrm{~g}$ peptic digest of animal tissue, $5.0 \mathrm{~g} \mathrm{NaCl}, 1.5 \mathrm{~g}$ beef extract, $1.5 \mathrm{~g}$ yeast extract, $15.0 \mathrm{~g}$ agar, $\mathrm{pH} 7.4 \pm 0.2$.

\subsection{Utilization of hydrocarbons by isolates}

The bacteria ability to degrade different hydrocarbons was verified using the method based on the redox indicator 2,6-dichlorophenol indophenol (DCPIP) (Hanson et al., 1993). The principle of this method is that during the oxidation of hydrocarbon by microorganisms, electrons are transferred to electron acceptors (sulphate, nitrate, $\mathrm{O}_{2}$ ). Whereas DCPIP is an electron acceptor, if it is added to the culture medium, it is possible to check the ability of the microorganism to use the substrate by observing the color change of DCPIP from blue (oxidized) to colorless (reduced).

Bacteria isolates grown on Nutrient Broth medium (Himedia Labs, consisting, per liter, of: $10.0 \mathrm{~g}$ peptone, $10 \mathrm{~g}$ beef extract, $5.0 \mathrm{NaCl}, \mathrm{pH} 7.3 \pm 0.1$ ) for $24 \mathrm{~h}$ were collected by centrifugation at $3600 \mathrm{rpm}$ for $10 \mathrm{~min}$ and washed three times with sterile saline solution $(0.85 \% \mathrm{w} / \mathrm{v})$ to remove the residual organic compounds from the medium. Then, the cell density in saline solution was adjusted to 0.8 according to the optical density (OD) at $\lambda=600 \mathrm{~nm}$. The bacteria $(100 \mu \mathrm{L})$ were inoculated in test tubes containing $2.0 \mathrm{~mL} \mathrm{BH}$ medium supplemented with $20 \mu \mathrm{L}$ diesel and $40 \mu \mathrm{L}$ DCPIP solution $(0.5 \mathrm{~g} / \mathrm{L})$. The test tubes were incubated at $30^{\circ} \mathrm{C}$ in agitation condition (150 rpm) and blue color disappearance was observed daily. Biodegradation of hexadecane, benzene, toluene and xylene by redox indicator-DCPIP test also were verified. When the aromatic hydrocarbons were used as carbon source in $\mathrm{BH}$ medium, $5 \mu \mathrm{L}$ were added instead of $20 \mu \mathrm{L}$ due to their toxicity. The strains that promoted decolorization or color reduction of $\mathrm{BH}$ medium supplemented with DCPIP and different hydrocarbons in shorter time were selected for identification and subsequent experiments.

\subsection{Morphological and biochemical characteristics}

The bacteria isolates selected in the redox indicator-DCPIP test were characterized by their morphological and biochemical characteristics. The morphological properties of strains were examined by optical microscopy using a Primo Star microscope (Carl Zeiss, Götting, Germany). Motility and biochemical tests such as gram staining, endospore-forming, carbohydrate fermentation, starch hydrolysis, methyl red and Voges-Proskauer reactions, citrate utilization test, catalase, oxidase, urease, and hydrogen sulfide were carried out according to Bergey's Manual of Determinative Bacteriology (Holt et al., 1994).

\subsection{Molecular identification}

The $16 \mathrm{~S}$ ribosomal RNA (rRNA) gene was analyzed to identify the selected bacteria strains. After the cells were cultured overnight in Nutrient Broth, the genomic DNA was extracted using Bacterial Genomic Miniprep Kit from Sigma Aldrich. The 16S rRNA gene fragment of strains was then amplified by PCR amplification using forward primer 27f (5'-AGAGTTTGATCCTGGCTCAG-3') and reverse primer 1492r (5'-GGTTACCTTGTTACGACTT-3'). The 16S rRNA PCR product was purified using GFX ${ }^{\mathrm{TM}}$ PCR Purification Kit (GE Healthcare) and sequenced by Genone (Rio de Janeiro, Brazil). The 16S rRNA sequences of strains were compared with the known sequences available at EzTaxon Database (EzBioCloud, 2018; Yoon et al., 2017). A phylogenetic tree was constructed in MEGA 7.0 software by carrying out the multiple alignments using Clustal W program (Thompson et al., 1994) and processing the data using the neighbor-joining method (Saitou and Nei, 1987). Bootstrap values were analyzed based on 1000 replications.

\subsection{Growth and diesel removal}

Each selected bacteria strain $(1.0 \mathrm{~mL}$ of $0.8 \mathrm{OD}$ bacterial suspension) was grown on $100 \mathrm{~mL} \mathrm{BH}$ medium supplemented with $1 \%(\mathrm{v} / \mathrm{v})$ diesel for 7 days, at $30^{\circ} \mathrm{C}$, on rotator shaker $(150 \mathrm{rpm})$. The growth of isolates was daily assessed by measuring the $\mathrm{OD}$ at $\lambda=600 \mathrm{~nm}$. After the period of incubation, diesel was extracted from the medium using $50 \mathrm{~mL}$ of cyclohexane and, after the organic solvent volatilization, the residual diesel was evaluated gravimetrically (Varjani and Upasani, 2016). The removal ratio of diesel means the reduction percentage of diesel. All biodegradation experiments were performed in triplicate.

\subsection{GC-MS analysis of residual diesel}

Quantification of the n-alkanes $\left(\mathrm{C}_{10}-\mathrm{C}_{27}\right)$ present in diesel after biodegradation by bacterial strains was performed at Mérieux NutriSciences Laboratory, in Piracicaba (São Paulo, Brazil), according to US EPA Method 8015-C (USEPA, 2000). The percentage of degradation of n-alkanes 
was calculated by comparison of the gas chromatograms of the undegraded control and the degraded sample for each bacteria strain.

\subsection{Detection of the alkane hydroxylase gene in bacterial isolates}

The purified DNA was screened by PCR to detect two catabolic genes that encode enzymes involved in alkane degradation pathways. Therefore, the alkB gene (group II) was amplified using the primers alk-2F (5'-GAGACAAATCGTCTAAAACGTAA-3') and alk-2R (5'-TTGTTATTATTCCAACTATGCTC-3') and the alkB gene (group III) was amplified using the primers alk-3F (5'-TCGAGCACATCCGCGGCCACCA-3') and alk-3R (5'-CCG TAGTGCTCGACGTAGTT-3'). The experimental protocol was developed according to Hassanshahian et al. (2012). Gene amplification was confirmed by running the obtained products on an agarose gel and ethidium bromide staining.

\subsection{Biosurfactant production and emulsification activity}

Biosurfactant production was determined by drop collapse test (Youssef et al., 2004). In the test, $2 \mu \mathrm{L}$ diesel was added to each well of a 96-well microliter plate lid. The lid was equilibrated for $1 \mathrm{~h}$ at room temperature, and then $5 \mu \mathrm{L}$ of cell free culture broth (obtained by centrifugation of bacterial culture grown in Nutrient Broth for $24 \mathrm{~h}$ ) was added to the surface of diesel. If the drop collapsed, the result was scored as positive. If the drop remained beaded, the result was scored as negative. To measure emulsification activity $\left(\mathrm{E}_{24}\right), 4 \mathrm{~mL}$ hydrocarbon (hexadecane, benzene, toluene, xylene or diesel) was mixed with $4 \mathrm{~mL}$ cell free culture broth for $2 \mathrm{~min}$ and left to stand for $24 \mathrm{~h}$. The $\mathrm{E}_{24}$ index was determined as the percentage of height of the emulsified layer divided by the total height of the liquid column.

\subsection{Data analysis}

Data analysis was conducted using the $\mathrm{R}$ (3.5.0) program for windows. Data were represented as the mean \pm standard deviation (SD) of the triplicates samples.

\section{Results}

\subsection{Isolation and characterization of bacteria}

Twenty-three hydrocarbon-degrading bacteria strains were isolated from enrichment cultures. All isolates were able to completely decolorize the DCPIP-BH medium with diesel indicating the degradation ability. Two strains (arbitrarily named as L26 and L30), however, decolorized faster the medium supplemented with diesel (within $72 \mathrm{~h}$ ). These strains also completely decolorized the DCPIP-BH medium after $24 \mathrm{~h}$ when hexadecane was used as hydrocarbon source and the medium was completely decolorized or the color has changed after 21 days when benzene, toluene or xylene was used. Table 1 lists the utilization of the hydrocarbons by bacterial strains L26 and L30.
L26 and L30 strains were first evaluated by classical biochemical tests (Table 2). They are rod shaped, Gram-positive, motile in the semi-solid culture medium, and endospore-forming. Posteriorly, the strains were identified by amplification and sequencing the 16S rRNA gene and comparing them to the database of known $16 \mathrm{~S}$ rRNA sequences. The results of molecular identification showed that L26 and L30 strains belong to the genus Bacillus. The phylogenetic tree based on 16S rRNA gene sequences showing the relationship of L26 and L30 strains with other Bacillus species are illustrated in Figure 2. The sequences of L26 and L30 strains were submitted to the GenBank with the accession numbers MG429820 and MG429814, respectively.

\subsection{Growth rate and diesel removal by strains}

The two selected strains, L26 and L30, were grown in $\mathrm{BH}$ medium supplemented with $1 \%(\mathrm{v} / \mathrm{v})$ of diesel for 7 days, at $30{ }^{\circ} \mathrm{C}$ and $150 \mathrm{rpm}$ agitation. After this period, the growth rates measured by OD of L26 and L30 were close, 1.542 and 1.616 , respectively. The removal of diesel, however, was higher by L30 strain (70.3\%) (Table 3).

Table 1. Utilization of different hydrocarbons by bacterial strains L26 and L30.

\begin{tabular}{lll}
\hline \multicolumn{1}{c}{ Carbon source } & L26 & L30 \\
\hline Diesel* $^{*}$ & $\mathrm{CD}$ & $\mathrm{CD}$ \\
Hexadecane $^{* *}$ & $\mathrm{CD}$ & $\mathrm{CD}$ \\
Benzene $^{* * *}$ & $\mathrm{RC}$ & $\mathrm{RC}$ \\
Toluene*** & $\mathrm{RC}$ & $\mathrm{RC}$ \\
Xylene $^{* * *}$ & $\mathrm{RC}$ & $\mathrm{CD}$ \\
\hline
\end{tabular}

Symbol: $\mathrm{CD}=$ Complete decolorization; $\mathrm{RC}=$ Reduction in color; *after $72 \mathrm{~h}$; **after $24 \mathrm{~h}$; ***after 21 days.

Table 2. Morphological and biochemical characteristics of bacterial strains L26 and L30.

\begin{tabular}{lcc}
\hline \multicolumn{1}{c}{ Characteristics } & L26 & L30 \\
\hline Morphology & Rod shaped & Rod shaped \\
Gram & - & - \\
Motility & + & + \\
Endospore-forming & + & + \\
Aerobic growth & + & + \\
Glucose fermentation & - & + \\
Saccharose fermentation & - & - \\
Lactose fermentation & - & - \\
Methyl red & - & - \\
Voges-Proskauer reaction & - & + \\
Citrate test & - & - \\
Starch hydrolysis & - & + \\
Catalase test & + & + \\
Oxidase test & + & - \\
Urease & - & + \\
Hydrogen sulfide test & - & - \\
\hline
\end{tabular}




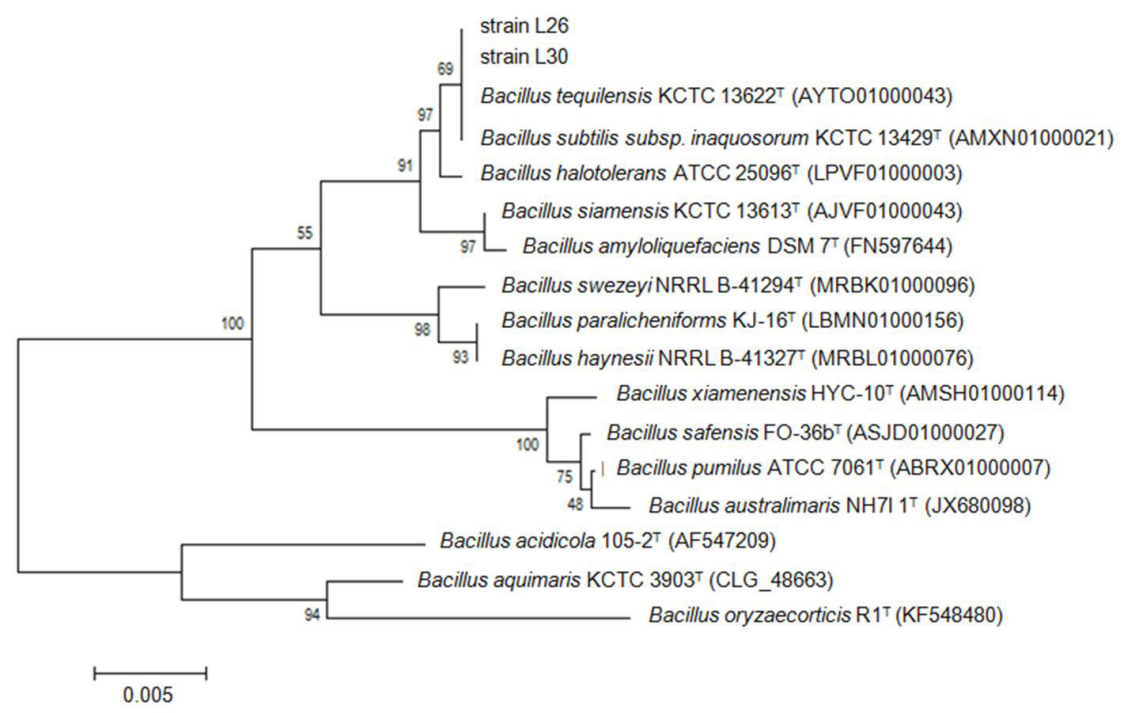

Figure 2. Neighbor-joining phylogenetic tree based on 16S rRNA gene sequences showing the relationships of strains L26 and L30 with other Bacillus species found in the EzTaxon Database. The bar indicates 0.005 substitutions per nucleotide position and values at nod represent percentage of 1000 bootstrap replicates.

Table 3. Growth and diesel removal by bacteria strains L26 and L30.

\begin{tabular}{ccc}
\hline Strain & $\begin{array}{c}\text { Growth rate } \\
\left(\mathbf{O D}_{\mathbf{6 0 0}}\right)\end{array}$ & $\begin{array}{c}\text { Percentage of diesel } \\
\text { removal }\end{array}$ \\
\hline L26 & $1.542 \pm 0.20^{*}$ & $70.3 \pm 3.83$ \\
L30 & $1.616 \pm 0.16$ & $46.5 \pm 2.41$ \\
\hline
\end{tabular}

*Values are mean \pm standard deviation of three replicates.

\subsection{Rate of degradation of n-alkanes from diesel}

The degradation percentage of n-alkane $\left(\mathrm{C}_{10}-\mathrm{C}_{27}\right)$ present in the diesel by bacteria strains L26 and L30 is shown in Figure 3. L30 strain was able to degrade all n-alkanes more efficiently than L26. L26 strain has low degradation abilities for n-alkanes with short chains $\left(\mathrm{C}_{10}-\mathrm{C}_{11}\right)$ and long chains $\left(\mathrm{C}_{22}-\mathrm{C}_{27}\right)$ most likely because short-chain $\mathrm{n}$-alkanes dissolve the cellular membrane and are toxic to bacteria and longchain n-alkanes have low solubility, inhibiting degradation by bacteria (Hassanshahian et al., 2012). The length of n-alkane seemed to interfere weakly with degradation abilities of L30 once the degradation rates of these fractions of alkanes were greater than $50 \%$ (except for $\mathrm{C}_{25}$ ).

\subsection{Biosurfactant production}

The ability of isolates to produce biosurfactants was measured by drop collapse test and emulsification activity $\left(\mathrm{E}_{24}\right)$ using various hydrophobic substrates. Both strains, L26 and L30, were positive for drop collapse test and had the values of $\mathrm{E}_{24}$ ranging from 0.0 to $14.3 \%$ for $\mathrm{L} 26$ and from 0.0 to $54.1 \%$ for L30 (Table 4). Emulsification activity was not observed when diesel was used as hydrophobic substrate. The complex nature of diesel (several hundred separate components have been identified) may have influenced this result.

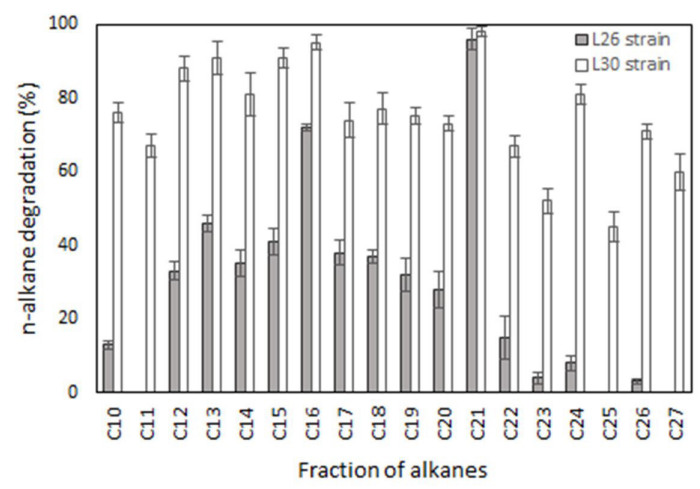

Figure 3. Percentage of n-alkane degradation from diesel by strains L26 and L30.

\subsection{Bacterial screening for the n-alkane hydroxylase gene (alkB)}

The presence of catabolic gene encoding n-alkane hydroxylase (group II and group III) was evaluated in the isolates L26 and L30 by PCR using specific primers. The results of PCR revealed that the strains are positive only for amplification of the alkB (group III) gene (Figure 4).

\section{Discussion}

Petroleum hydrocarbon biodegradation by natural populations of microorganisms represents one of the primary mechanisms through which these pollutants can be eliminated from the environment (Morais and Tauk-Tornisielo, 2009). Hydrocarbon-degrading microorganisms are present in many environments, even in pristine ones. However, prior exposure to hydrocarbons largely influences their abundance 
Table 4. Measurement of emulsification activity $\left(\mathrm{E}_{24}\right)$ of two bacteria isolates using various hydrophobic substrates.

\begin{tabular}{cccccc}
\hline \multirow{2}{*}{ Strain } & \multicolumn{5}{c}{ Emulsification activity $\left(\mathbf{E}_{\mathbf{2 4}} \mathbf{\%}\right)$} \\
\cline { 2 - 6 } & Hexadecane & Benzene & Toluene & \multicolumn{1}{c}{ Xylene } & Diesel \\
\hline L26 & $8.6^{*} \pm 1.00$ & $5.9 \pm 0.65$ & $14.3 \pm 0.68$ & $5.6 \pm 0.25$ & 0 \\
L30 & $19.4 \pm 1.91$ & $31.4 \pm 0.96$ & $51.4 \pm 1.34$ & $54.1 \pm 1.01$ & 0 \\
\hline
\end{tabular}

*Values are mean \pm standard deviation of three replicates.

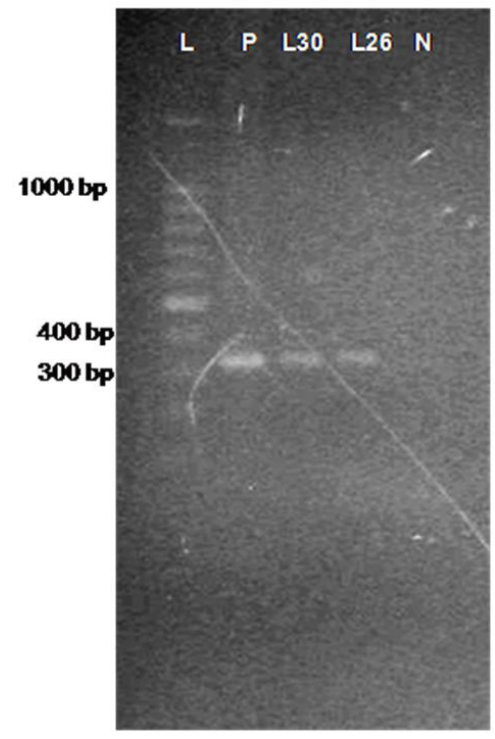

Figure 4. PCR detection of alk-B hydroxylase genes (group III) in isolate strains: L, 100 bp DNA size marker Ladder; P, positive control (Pseudomonas aeruginosa ATCC 27853); N, negative control. L30 and L26 are the bacteria strains evaluated.

in various environments (Varjani and Upasani, 2016) and communities exposed to hydrocarbons become adapted. This phenomenon of adaptation is a consequence of three interrelated mechanisms: (i) induction and/or depression of specific enzymes that degrade hydrocarbons; (ii) genetic changes which result in new metabolic capabilities; and (iii) selective enrichment of microorganisms able to transform the hydrocarbons (Leahy and Colwell, 1990). Presumably, the microbiota of this study area became adapted to hydrocarbon contamination, which has been detected since 2006.

Among microorganisms, bacteria have been reported as primary and active agents in hydrocarbon degradation (Varjani and Upasani, 2016). Bacterial species that degrade hydrocarbons are widely distributed in nature and are not restricted to only a few genera. Some of the various genera of bacteria that have been reported as hydrocarbon degraders include Acinetobacter, Pseudomonas, Gordonia, Rhodococcus, Cobetia, Halomonas, Alcanivorax, Marinobacter, Microbacterium, Corynebacterium, Ochrobactrum, Stenotrophomonas and Hahella (Morais and Tauk-Tornisielo, 2009; Hassanshahian et al., 2012; Abed et al., 2014; Hassanshahian et al., 2014). The genus Bacillus is another outstanding bacterial genus reported as petroleum hydrocarbon degrader. Their ability to form spores when nutrients are limiting makes species of Bacillus self-sustainable bioremediation tools (Oyetibo et al., 2017). Uad et al. (2010) described eight hydrocarbon-degrading strains of Bacillus from seawater and sediments from the surroundings of an oil tanker wreck. The strains, Bacillus thuringiensis (one strain) and Bacillus pumilus (7 strains), were able to grown on solid media containing naphthalene, phenanthrene, anthracene and pyrene as the sole carbon source. Patowary et al. (2016) developed an efficient consortium with the strains Bacillus cereus R2 and Bacillus pumilus KS2, which was used to degrade crude oil. After 5 weeks of incubation, the consortium showed degradation of up to $84.15 \%$ of total petroleum hydrocarbons.

Several species of Bacillus produce biosurfactants, a group of surface active molecules with emulsifying activity due to their ability to reduce surface and intersurface tension (Hassanshahian et al., 2014). This property is considered to be a biological strategy to increase the bioavailability of poorly accessible carbon sources, such as hydrocarbons, and to enhance the biodegradation rates. Hassanshahian et al. (2014) isolated 15 crude oil degrading bacteria from oil contaminated sites in the Persian Gulf. These authors found that the strain that showed the best crude oil biodegradation, Corynebacterium variabile PG-Z, had the highest emulsification activity and biosurfactant production among all isolates. In this study, strain L30 showed higher $\mathrm{E}_{24}$ values than strain L26 (Table 4), and the degradation of $\mathrm{n}$-alkanes by L30 was more efficient. These results indicated a relationship between the levels of biosurfactant production and hydrocarbon biodegradation.

Biodegradation of n-alkanes by bacteria commonly starts with oxidation of alkanes to the corresponding alcohols. After, these alcohols are oxidized to aldehydes, and, finally, fatty acids, which are used in the central catabolic pathway of the cells (Tanase et al., 2013). The oxidation of alkanes to alcohols is the crucial step to initiate the degradation of alkanes and this reaction is catalyzed by the enzyme alkane hydroxylase or AlkB. The catabolic genes that encode alkane hydroxylases have been found in several bacterial populations from environments contaminated with hydrocarbons (Hassanshahian et al., 2012; Tanase et al., 2013). These alkane hydroxylase genes have been classified into three groups based on phylogenetic analysis: group (I) enconding alkB, which catalyzes short-chain alkanes $\left(\mathrm{C}_{6}-\mathrm{C}_{12}\right)$; group (II) encoding alkM, which catalyzes long-chain alkanes $\left(>\mathrm{C}_{12}\right)$ and group (III) encoding alkB, which is unknown for substrate specificity (Kohno et al., 2002). Hassanshahian et al. (2012) studied the distribution 
of alk-B among the isolates of two contaminated marine sites and concluded that group (II) alkB genes predominated in the Caspian Sea, whereas group (III) genes were more prevalent in the Persian Gulf. In this study, the strains L26 and L30 presented the alkB gene group (III) and this result validated the n-alkane degradation observed.

\section{Conclusion}

The results of this study indicated that from 23 hydrocarbon-degrading bacteria isolated from a station leaking-contaminated groundwater located in the Southern Amazon, Brazil, two strains (Bacillus sp. L26 and Bacillus sp. L30) have the highest potential to use different hydrocarbons (diesel, hexadecane, benzene, toluene and xylene) as the sole carbon source. These strains harbored the alkB gene (group III), which corroborated with a good alkane degradation performance, mainly by strain L30. The hydrocarbon degrading properties of these strains suggest that they can be useful in bioremediation of hydrocarbon polluted sites.

\section{Acknowledgements}

This study was financed in part by the Coordenação de Aperfeiçoamento de Pessoal de Nível Superior - Brasil (CAPES) - Finance Code 001

\section{References}

ABED, R.M.M., AL-SABAHI, J., AL-MAQRASHI, F., AL-HABSI, A. and AL-HINAI, M., 2014. Characterization of hydrocarbon-degrading bacteria isolated from oil-contaminated sediments in the Sultanate of Oman and evaluation of bioaugmentation and biostimulation approaches in microcosm experiments. International Biodeterioration \& Biodegradation, vol. 89, pp. 58-66. http://dx.doi.org/10.1016/j.ibiod.2014.01.006.

BUSHNELL, L.D. and HAAS, H.F., 1941. The utilization of certain hydrocarbons by microorganisms. Journal of Bacteriology, vol. 41, no. 5, pp. 653-673. PMid:16560430.

EZBIOCLOUD [online], 2018 [viewed 24 July 2018]. Available from: http://www.ezbiocloud.net/taxonomy

HANSON, K.G., DESAI, J.D. and DESAI, A.J., 1993. A rapid and simple screening technique for potential crude oil degrading microorganisms. Biotechnology Techniques, vol. 7, no. 10, pp. 745-748. http://dx.doi.org/10.1007/BF00152624.

HASSANSHAHIAN, M., EMTIAZI, G. and CAPPELLO, S., 2012. Isolation and characterization of crude-oil-degrading bacteria from the Persian Gulf and the Caspian Sea. Marine Pollution Bulletin, vol. 64, no. 1, pp. 7-12. http://dx.doi.org/10.1016/j. marpolbul.2011.11.006. PMid:22130193.

HASSANSHAHIAN, M., ZEYNALIPOUR, M.S. and MUSA, F.H., 2014. Isolation and characterization of crude oil degrading bacteria from the Persian Gulf (Khorramshahr Provenance). Marine Pollution Bulletin, vol. 82, no. 1-2, pp. 39-44. http:// dx.doi.org/10.1016/j.marpolbul.2014.03.027. PMid:24703768.

HOLT, S.G., KRIEY, N.R., SNEATH, P.H.A., STALEY, J.T, and WILLIAMS, S.T., 1994. Bergey's manual of determinative for bacteriology. 9th ed. New York: Williams and Wilkins, $787 \mathrm{p}$.
KOHNO, T., SUGIMOTO, Y., SEI, K. and MORI, K., 2002. Design of PCR primers and gene probes for general detection alkane-degrading bacteria. Microbes and Environments, vol. 17, no. 3, pp. 114-212. http://dx.doi.org/10.1264/jsme2.17.114.

LEAHY, J.G. and COLWELL, R., 1990. Microbial degradation of hydrocarbons in the environment. Microbiological Reviews, vol. 54, no. 3, pp. 305-315. PMid:2215423.

MORAIS, E.B. and TAUK-TORNISIELO, S.M., 2009. Biodegradation of oil refinery residues using mixed-culture of microorganisms isolated from a landfarming. Brazilian Archives of Biology and Technology, vol. 52, no. 6, pp. 1571-1578. http:// dx.doi.org/10.1590/S1516-89132009000600029.

OYETIBO, G.O., CHIEN, M.F., IKEDA-OHTSUBO, W., SUZUKI, H., OBAYORI, O.S., ADEBUSOYE, S.A., ILORI, M.O., AMUND, O.O. and ENDO, G., 2017. Biodegradation of crude oil and phenanthrene by heavy metal resistant Bacillus subtilis isolated from a multi-polluted industrial wastewater creek. International Biodeterioration \& Biodegradation, vol. 120, pp. 143-151. http://dx.doi.org/10.1016/j.ibiod.2017.02.021.

PATOWARY, K., PATOWARY, P., KALITA, M.C. and DEKA, S., 2016. Development of an efficient bacterial consortium for the potential remediation of hydrocarbons from contaminated sites. Frontiers in Microbiology, vol. 7, pp. 1092. http://dx.doi. org/10.3389/fmicb.2016.01092. PMid:27471499.

SAITOU, N. and NEI, M., 1987. The neighbor-joining method: a new method for reconstructing phylogenetic trees. Molecular Biology and Evolution, vol. 4, no. 4, pp. 406-425. http://dx.doi. org/10.1093/oxfordjournals.molbev.a040454. PMid:3447015.

TANASE, A.M., IONESCU, R., CHICIUDEAN, I., VASSU, T. and STOICA, I., 2013. Characterization of hydrocarbon-degrading bacterial strains isolated from oil-polluted soil. International Biodeterioration \& Biodegradation, vol. 84, pp. 150-154. http:// dx.doi.org/10.1016/j.ibiod.2012.05.022.

THOMPSON, J.D., HIGGINS, D.G. and GIBSON, T.J., 1994. CLUSTAL W: improving the sensitivity of progressive multiple sequence alignment through sequence weighting, position-specific gap penalties and weight matrix choice. Nucleic Acids Research, vol. 22 , no. 22 , pp. 4673-4680. http://dx.doi.org/10.1093/ nar/22.22.4673. PMid:7984417.

UAD, I., SILVA-CASTRO, G.A., POZO, C., GONZÁLEZLÓPEZ, J. and CALVO, C., 2010. Biodegradative potential and characterization of bioemulsifiers of marine bacteria isolated from samples of seawater, sediment and fuel extracted at 4000 $\mathrm{m}$ of depth (Prestige Wreck). International Biodeterioration \& Biodegradation, vol. 64, no. 6, pp. 511-518. http://dx.doi. org/10.1016/j.ibiod.2010.06.005.

UNITED STATES ENVIRONMENTAL AGENCY - USEPA, 2000 [viewed 24 July 2018]. Method 8015C: nonhalogenated organics by gas chromatography [online]. Washington: USEPA. Available from: https://www.epa.gov/sites/production/files/2015-12/ documents $/ 8015 \mathrm{c}$.pdf

VARJANI, S.J. and UPASANI, V.N., 2016. Biodegradation of petroleum hydrocarbons by oleophilic strain of Pseudomonas aeruginosa NCIM 5514. Bioresource Technology, vol. 222, pp. 195-201. http://dx.doi.org/10.1016/j.biortech.2016.10.006. PMid:27718402.

VARJANI, S.J., 2017. Microbial degradation of petroleum hydrocarbons. Bioresource Technology, vol. 223, pp. 277-286. http://dx.doi.org/10.1016/j.biortech.2016.10.037. PMid:27789112. 
YOON, S.H., HA, S.M., KWON, S., LIM, J., KIM, Y., SEO, H. and CHUN, J., 2017. Introducing EzBioCloud: a taxonomically united database of $16 \mathrm{~S}$ rRNA gene sequences and whole-genome assemblies. International Journal of Systematic and Evolutionary Microbiology, vol. 67, no. 5, pp. 1613-1617. http://dx.doi. org/10.1099/ijsem.0.001755. PMid:28005526.
YOUSSEF, N.H., DUNCAN, K.E., NAGLE, D.P., SAVAGE, K.N., KNAPP, R.M. and MCINERNEY, M.J., 2004. Comparison of methods to detect biosurfactant production by diverse microorganisms. Journal of Microbiological Methods, vol. 56, no. 3, pp. 339-347. http://dx.doi.org/10.1016/j.mimet.2003.11.001. PMid:14967225. 